DOI: $10.11649 /$ abs.2020.012

\title{
Вероника Гирининкайте
}

Вильнюсский университет

Вильнюс

veronika.girininkaite@mb.vu.lt

https://orcid.org/0000-0002-2127-5594

\section{Языковые особенности Дневника Витольда Цивиньского}

\section{1. Частные документы как объект исследования в социолингвистике}

Изучение зафиксированных на письме различных вариантов языка обогащает наше понимание истории его развития и возможных способов лингвистического бытования. Неоднократно отмечалось (Elspass, 2014; Koch \& Oesterreicher, 1980; Nevalainen \& Raumolin-Brunberg, 2014; Romaine, 2009), что для социолингвиста наиболее продуктивно изучение частных документов, изначально не предназначавшихся для широкого круга читателей и специально не редактированных. Таковы личные письма, дневниковые записи, язык которых зачастую близок к непринужденной устной речи. Указывалось также, что эта разновидность письменности изучена недостаточно (Беликов \& Крысин, 2001, с. 315).

\section{1. История рукописи}

В статье рассмотрены языковые особенности Дневника молодого человека, студента ветеринарии Витольда Цивиньского (1887-1910). Дневник (далее - 
ДВЦ) записан в 27 общих тетрадях размером около $12 \times 17$ см, объем которых варьируется от 42 до 226 страниц. В подавляющем большинстве случаев текст записан на лицевых страницах, на оборотных же сторонах листов часто помещены открытки, фотографии, полученные письма. Общий объем рукописи превышает 3500 листов. Большая часть текста записана по-польски. По мере изучения автором литовского, увеличивалась и доля этого языка в рукописи. Наряду с этими двумя основными языками, в рукописи присутствуют русские, французские, немецкие фрагменты, а также элементы других известных автору языков. Распределение языков в рукописи отражено в таблице Приложения.

Судя по отмеченным в рукописи датам, свой Дневник (по крайней мере, ту его часть, которая доныне хранится в отделах рукописей библиотек Вильнюсского университета и Академии Наук Литвы), Витольд Цивиньский начал писать около 1904 года, по окончании обучения в реальном училище, и более или менее регулярно продолжал писать на протяжении почти шести лет. Записи ранних воспоминаний, в частности, о поездке 1902 года в Краков и Вену, также датированы 1904 и 1905 годами (LMAVB RS, F194-10). После смерти автора (15.10.1910), его родственник по материнской линии Окулич передал рукопись в учрежденный в 1923 году Каунасский музей литературы (Rašliavos muziejus). Оттуда она попала в библиотеку каунасского Университета Витовта Великого, а после его закрытия в 1950 г. была перевезена в Вильнюс.

\section{2. Происхождение Витольда Цивиньского}

Отцу автора Дневника, дворянину Иерониму Цивиньскому принадлежало имение Митува (Mituva, Mitów) в Литве, мать Антонина Окулич также происходила из дворян, владельцев расположенного неподалеку поместья Лотовяны (Latavėnai) (Jankauskas, 2010). Свое родовое гнездо Цивиньские могли навещать лишь во время каникул: отец занимал видный пост инженера на железной дороге Российской Империи и обязан был работать там, куда его назначали. Вместе с ним по разным российским городам кочевала и его семья. Сменялись адреса - Владимир, Самара, Казань, Тамбов. Витольд, третий сын, был рожден в Москве, по его собственному свидетельству, на Нижегородском вокзале (LMAVB RS, F194-10, л. 107). Пару лет спустя мать его умерла, и Иероним Цивиньский женился вторично на ее сестре, Каролине Окулич. У них также родились дети ${ }^{1}$.

${ }^{1}$ Подробная генеалогия семьи представлена на сайте <www.geni.com>, некоторые сведения помещены на сайте, посвященном выходцам из окрестностей города Аникщяй <www.anykstenai.lt> (Pasaulio anykštènu bendrija, n.d.). 
Витольд воспитывался в польском патриотическом духе. В семье его обучением занимались тети и бабушки (фрагменты их переписки на эту тему сохранились в Дневнике). Витольд окончил российскую школу, тамбовское реальное училище. В связи с занятостью отца имение Цивиньских Митува сдавалось в аренду, а летние каникулы дети проводили у Окуличей в Лотовянах. Деятельные женщины семейства - бабушки и тети Витольда - хранили память о восстаниях XIX века и поддерживали в поместье демократический, просветительский дух ${ }^{2}$.

\section{2. Жизненный путь автора и языки ДВЦ}

Обучению молодого поколения в семье уделялось много внимания. Старшие братья автора ДВЦ выучились на врача и инженера; сестра матери Витольда, Анна, получила в Варшаве образование акушера (впоследствии она вышла замуж за ботаника и фитопатолога Йозефа Тшебиньского ${ }^{3}$. Вероятно, пример дяди послужил тому, что Витольд выбрал профессию агронома и начал обучение в университете в Лейпциге. Годы учебы в Германии отразились на текстах ДВЦ все усиливающимся влиянием немецкого языка, наплывом германизмов (что отметил и сам автор ДВЦ). С другой стороны, сплошной немецкий текст в ДВЦ редок, в основном это включенные в дневник конспекты лекций. Известия о революционных событиях 1905 года сильно повлияли на молодого человека. Несмотря на возмущение отца, он бросил учебу, вернулся в Литву и провел неспокойную зиму в имении Лотовяны. Осознав, что профессия агронома его не привлекает, он поступил на ветеринарию. Одной из причин такого выбора было желание получить доходную профессию, которая позволила бы стать материально независимым от семьи. Проучившись некоторое время в Берлинском королевском училище ветеринарии, в 1907 году он перевелся в Институт ветеринарии в Дерпте (современный Тарту в Эстонии). Там он сблизился с молодыми литовскими интеллектуалами, вступил в местное литовское студенческое общество, посе-

${ }^{2}$ Юзефа Повицкайте Окулич открыла для крестьян тайную библиотеку и обучала дворню грамоте, причем, что важно, польской или литовской, в зависимости от пожеланий обучаемого (Trzebińska-Wróblewska, 2002, c. 17). Тетя Юзефа, ее соседи и помощники периодически оказывались в заточении по подозрениям в нелегальной деятельности. Похоже, что пламенность и самоотверженная деятельность во имя справедливости были чертой семейной - сестра Юзефы Фелиция Повицкайте-Борткявичене, корреспондент, редактор газет, пошла в политику от социал-демократов и сыграла важную роль в становлении Литовского государства. Вероятно, не без ее участия в 1906 г. в Лотовянах произошел первый в Литве съезд движения за права женщин. Среди других родственников Окуличей были журналисты и предприниматели.

${ }^{3}$ Józef Trzebiński (о нем: Trzebińska-Wróblewska, 2002; Žilinskaitė et al., 2017). 
щал уроки литовского языка, участвовал в студенческой самодеятельности. Это способствовало все более частому и разнообразному употреблению литовского языка в ДВЦ.

\section{1. Польский язык ДВЦ}

Польский язык ДВЦ своеобразен. Во-первых, это социолект дворян Литвы. Особенностям этого социолекта посвящены работы многих исследователей (Adomavičiūtè-Čekmonienè \& Čekmonas, 1999; Karaś et al., 2001; Sawaniewska-Mochowa, 2002; Sawaniewska-Mochowa \& Zielińska, 2007). Наиболее заметные его свойства - более мягкое произношение согласных, обилие диминутивов, архаичных форм, преобладание разговорного стиля, специфическое падежное согласование. Во-вторых, польский автора ДВЦ - это язык человека, который грамматику специально не изучал. Написание во многих случаях приближено к фонетическому, а орфография довольно стихийна (различные варианты написания одного и того же слова возможны и на одной странице).

Несоответствие польской орфографической норме можно наблюдать, например, в некоторых употреблениях $u$ и ó: Kosciuł; muwił [=ó]; warónków, róch $[=\mathrm{u}]$. Нередко автор использует знаки, для нормативной польской орфографии соответствующего периода (как и современной) не характерные (do Рoniewieža; wyježdžamy, buržua, na ržysko [=і்]). Крайне частотная в ДВЦ графема $\check{Z}$ на первый взгляд может казаться влиянием литовского языка, но скорее всего, это черта архаичного польского правописания, имевшего свои традиции на территории Литвы (Sawaniewska-Mochowa, 2002, с. 79). По фонетическому принципу в ДВЦ зачастую передаются шипящие согласные (pszygode [cр. нормативное przygode]). Кроме того, автор не всегда отмечал палатализацию (we srodku, zjedlismy [=ś] trzežwy [=ź]) сохранял архаичные удвоенные согласные (po rossyjsku).

Что касается лексики, довольно интимному, дружескому тону дневника соответствует обилие разговорной лексики (naskrobać 'написать'; wytrabit 'выпил'; skapować 'смекнуть' - cp. характеристики этих лексем в USJP, 2003), элементы просторечия (nažarłem się, nażreć się 'нажраться' - см. USJP, 2003); диалектизмы (реwnikiem 'наверняка', - cM. SJPD, 1958-1969; SGP, 1900-1911), жаргонизмы (pagrąžony, вероятно, должно быть pogrążony 'погруженный, влюбленный' - переносное значение согласно SJPD, 1958-1969). Довольно часто Цивиньский употреблял фонетическую запись разговорного trza вместо trzeba ('следовало бы'). Сокращение psor вместо profesor ('профессор') до сегодняшнего дня функционирует в сленге школьников и студентов (Czeszewski, 2001, с. 223) как способ выражения симпатии или же снисходительности по 
отношению к профессору. В тексте замечены и напоминающие жаргонизмы лексемы fetka, faca, контекстуально понимаемые как варианты слова facetka ('незнакомая девушка', разг., согласно USJP, 2003).

Цивиньский употреблял и традиционные для среды литовского поместья литуанизмы (rogajcza, rogojsz, ср. лит. ragaišis 'род белого хлеба'; za swirnem, cp. лит. svirnas 'амбар'; bucze, ср. лит. bučius 'верша, мерёжа (рыболовецкая снасть) и русизмы. В тексте ДВЦ встречается много русизмов и литуанизмов, которые в общепольском не использовались. В ДВЦ регионализмы более частотны в текстах, связанных с бытом, кулинарией и традиционными видами промысла, что вообще характерно для этого типа лексики (Rutkowska, 2012; Smoczyński, 2001).

Наряду с традиционными регионализмами, заметны и заимствования, которые вполне могли быть индивидуальными окказионализмами. Например, во фразах wystudziłem but swój 'я выстудил свою квартиру'; kąsały mnie... $d z i s ́$ w nocy... blusy 'сегодня ночью меня кусали блохи' выступают литуанизмы but ('квартира'), blusy ('блохи’) (=mieszkanie, pchty, ср. лит. butas, blusos), а в примерах póki do czego nie doprę 'пока до чего-нибудь не додумаюсь', idziemy drychać 'идем спать' - русизмы (ср. допереть 'додуматься', дрыхнуть 'спать').

Цивиньский понимал, что его польский язык далек от совершенства и неоднократно собирался изучить правила грамматики ${ }^{4}$.

\section{2. Литовский язык ДВЦ}

В виде отдельных фраз и лексем литовский язык в ДВЦ появляется уже в 1904 г.: Sudievu, sudievu Letuva 'Прощай, прощай Литва' (VUB RS, F1-D1024, л. 107); trzeba czyscić zęby, pakować czomodan i važiot $z$ nim 'надо чистить зубы, собирать чемодан и ехать с ним' (VUB RS, F1-D1028, л. 55); kiepskie, ale nie visiškaj 'плохо, но не окончательно плохо' (VUB RS, F1-D1029, л. 65). К сознательному изучению литовского Цивиньский приступил довольно рано: в 1902 году, будучи пятнадцатилетним юношей, он сообщил в письме бабушке, что освоил уже немало литовских слов (LMAVB RS, F194-54v).

Графика литовского языка ДВЦ своеобразна. Написание некоторых лексем может удивлять современного читателя, однако известно, что в то время стандартизация языка была еще не вполне завершена (Jonikas, 1972; Palionis, 1995; Venckienè, 2007).

Интереснее то, что во многих, особенно первых литовских записях Цивиньского отражен окружавший его говор Лотовян, разновидность восточ-

\footnotetext{
${ }^{4}$ Об этом он писал, например, в письмах (VUB RS, F1-D1045, л. 74-75 и F1-D1048, л. 30).
} 
ного аукштайтского диалекта (Markevičienè, 2011; Zinkevičius, 1978). Это отличающие аукштайтское произношение сочетания in, un, соответствующие стандартным en, an (kurinsiu [=en], dunti [=dantys], kusneli [=kąsneli]]), разновидности эпентез (nuvejau [=nuejau], jeméme [=ёmème], vuodega [uodega]), подмена ударного гласного дифтонгом (visuokiu [visokiu], įduomi [=idomi]), заметная редукция гласного в окончании (išvažiava [=išvažiavo], numiria [=numirè], su Jono [=Jonu]).

Характерно также диалектное стяжение некоторых форм (viškai [=visiškai], kol [=kodèl], gausma [=gausime]). Что касается морфологии, язык ДВЦ отличает частое употребление форм архаичного на сегодняшний день двойственного числа (pasipažinova, kalbejova ${ }^{5}$ ), а также характерные для узуса начала века отличия от современного управления падежей (Išpardaviau: visi kalendoriai ${ }^{6}$, buva ant vakzolo $)$.

В целом литовский язык в ДВЦ представляет собой редкий пример хроники изучения и становления нового языка. От робких попыток (впрочем, изучающего язык Цивиньского отличает именно похвальная смелость и упорство в овладении новыми формами речи) совершается переход ко вполне полноценному и умелому выражению мысли. Впрочем, этот процесс не был однонаправленным (увеличение и временный спад литовского элемента в ДВЦ показывают подсчеты, представленные в таблице Приложения). Значительный прогресс в овладении орфографией и в речевых навыках позволяет предположить, что «за скобками» Дневника остались долгие занятия литовским языком, упражнения в нем и редкая самодисциплина автора этого текста ${ }^{8}$.

\section{3. Русский язык ДВЦ}

Русским языком автор ДВЦ владел в совершенстве. Это касается не только редкого богатства фразеологии и тонких нюансов стиля, которые он способен был передать, но и использовавшихся им стилей правописания. Обновленная орфография русского языка была официально принята в 1904 году (а к применению рекомендована только в 1918) (Григорьева, 2004), но среди прогрессивно настроенной части российского общества тенденция

5 'Мы [двое] познакомились, разговаривали'.

6 'Распродал: все календари' (VUB RS F1-D1034, л. 29). Именительный падеж вместо винительного (=kalendorius).

7 'Был на вокзале' (VUB RS F1-D1033, л. 155). Сочетание предлога и существительного вместо локатива (=vakzole).

${ }^{8}$ О круге чтения Цивиньского и о том, как он изучал литовский язык, см. Girininkaite, 2017b, 2018. 
к упрощению письма заметна по крайней мере с первой половины XIX века. Доля русского языка в ДВЦ невелика. В основном русский язык выявляется в письмах. В зависимости от адресата Цивиньский писал и в старом стиле (в черновиках официальных прошений, письмах к сестре), и в новом (например, в письмах, адресованных однокласснику). Вот пример русского написания в черновике официального заявления (старый стиль написания), осенью 1907 года:

Г. Вилкомирскому Исправнику дворянина Ви. Іер. Ц. а прошеніе. При аресть и сопряженнымб съ нимб обыскб моихъ вбщей, произведенномг чиновникомг Азоркинымб, а затбмб, 11 ію юня сего года, Вами лично, у меня были отобраны для выясненія ихъ содержанія нбсколько литовских книгъ (VUB RS F1-D1044, л. 20).

По сравнению с приведенным примером, написание в дружеском послании бывшему однокласснику Болеславу Стравинскому в Тамбов (17.05.1905) модернизировано, хотя и не полностью (по соседству с приведенным фрагментом замечены слова с графемой и десятеричным: Россіи, физиіократизм, оріэнтироваться):

Если ты будешь в Гродне в то время, то заеду из Вильна, или ты сам туда пожалуешь, быть может. Все будет стоить 40 рублев. По окончании письменных пришли „весточку“. Сегодня среда, день с особенно интересными лекииями (VUB RS F1-D1030, л. 50).

Остальные примеры русского написания в ДВЦ располагаются между двумя показанными примерами. При этом создается впечатление, что естественным, немаркированным для автора был именно старый стиль написания; это и понятно, учитывая то, что незадолго до создания ДВЦ он весьма успешно 9 окончил реальное училище в Тамбове.

\section{4. Другие языки (немецкий, французский, английский, латынь, идиш, латышский)}

Количество фрагментов, записанных по-немецки, и германизмов в ДВЦ значительно возрастает в конце 1904 года. Это было связано с проживанием автора в Германии и конспектированием лекций на языке оригинала, а также с появлением в его быту новых реалий. В ДВЦ отсутствуют заглавные буквы у существительных, появляется особая графема Ŭ (dŭrch; im Ă̌slande bleiben; ŭnd).

9 В архиве Цивиньского сохранились свидетельство об окончании 4-го класса училища с оценками (LMAVB RS, f. 194, b. 1) и несколько школьных сочинений. 
Что касается лексики, в ДВЦ это отчасти традиционные для польской речи дворян германизмы (na banhofie ${ }^{10}$ 'на вокзале', dla frajdy ${ }^{11}$ 'на радость', $z$ festu' ${ }^{12}$ 'с праздника'), а также новые для автора реалии либо заимствования, сопровождающиеся смешением кодов ( $z$ umszlagiem 'c компрессом', fieberu niema 'нет температуры'). По-видимому, ни в свободное время, ни во время занятий языкового барьера Цивиньский не ощущал. Возможно, это было связано с тем, что дети Цивиньских, как свидетельствует письмо Витольда бабушке, за столом обязаны были общаться по-немецки (LMAVB RS, F194-10, л. CLXI).

Что касается иных языков ДВЦ, то они представлены фрагментарно. В упомянутом письме бабушке сказано, что в дом приходила учительница-француженка. По-французски Цивиньский читал ${ }^{13}$. Элементы французского языка в ДВЦ - это в основном сентенции и общеупотребительные крылатые фразы.

То же можно сказать и об элементах латинского языка. Количество латинизмов увеличилось, когда автор начал изучать язык для своей специальности и готовясь к экзамену.

В польском языке ДВЦ замечено небольшое количество заимствований из идиша и иврита. Большинство этих лексем известны в разговорном польском. Таковы rejwach ('беспорядок', разг. согласно SJPD, 1958-1969), bachury ('парни', согласно SJPD, 1958-1969 yстар., из иврита), kabała ('кабала', название определенного пасьянса, согласно SJPD, 1958-1969 из иврита), miszugen ('блаженный, дурачок', согласно SWO, 1921, 1927 из иврита). А чрезвычайно частотное в ДВЦ geldele ('деньги, денежки') в словарях польского языка обнаружено не было. Возможно это было слово, принятое лишь в кругу семьи (употреблено и в письме отца, Иеронима Цивиньского).

Автор ДВЦ неоднократно упоминал, что изучает латышский язык. На этом языке он читал периодические издания, но в ДВЦ обнаружено лишь несколько латышских слов.

\section{3. Многоязычие и типы переключения кодов}

Питер Мюйскен различает три основных структурных типа переключения кодов: вкрапления (элемент, чаще всего лексема, одного языка вставляется в контекст другого языка), собственно переключение кодов (начатая на одном

\footnotetext{
${ }^{10}$ SJPD (1958-1969) определяет как устаревшее.

11 SJPD (1958-1969) определяет как разговорное.

12 SJPD (1958-1969), в третьем значении 'празднество', определено как разговорное.

13 Список прочитанных Цивиньским книг и статей (LMAVB RS, F194-3).
} 
языке фраза заканчивается на другом языке) и конгруэнтную лексикализацию (переход между языками может совершаться неоднократно, границы между языками не вполне очевидны) (Muysken, 2000). В ДВЦ присутствуют все эти типы (Wogule, все благополучно, tylko..." ${ }^{14}$ budzik swolocz nicht ganz praktisch"; caca-śs chłopczyk! Perskaičiou 48 str. ir presque tout comprie $\left.{ }^{16}\right)$.

Наряду с примерами обыкновенной интерференции между языками (например, głownego chriebta nie było widaćc ${ }^{17}$ ), в тексте видны и сознательно созданные, подобранные автором сочетания элементов разных языков. Как показал анализ примеров (Girininkaite, 2019), к этому приему Цивиньский мог прибегать, желая достигнуть большей точности и выразительности. Такой сознательный прием может быть обозначен как монтаж языков. Среди функций этого явления были уточнение, связанное с осознанием непереводимости лексем ${ }^{18}$, межъязыковая игра (Blague des blagues ${ }^{19}$ ), цитирование, эмфаза (фраза, которую требуется подчеркнуть, повторяется на разных языках, например Zrozum, že nastrój, to swięta rzecz. Res sacra ${ }^{20}$; Sniłem J'ai rêvé... Jai revé Sapnavau, mat, negražiai skamba Traum Rêve ${ }^{21}$ ) и эвфемизм. Например, заметно, что при употреблении бранной лексики автор ДВЦ довольно часто избирал иную транслитерацию (возможно для смягчения эффекта, Co oni sobie, sukiny demu, mysla? ${ }^{22}$; польское Юxa!?3), а говоря о деньгах [низменном, недостойном предмете?], чаще всего прибегал к их непрямому или иноязычному названию: monees, fenigi, fajgli, grosze, гельделе ('деньги', заимствования из англ., нем., польск., идиш).

В целом можно отметить, что обилие языкового материала в ДВЦ и его свободное комбинирование способствовали усилению выразительности текста.

14 'В целом все благополучно, только...' (VUB RS F1-1035, л. 13). Вкрапление русского в польскую фразу.

15 'Будильник, сволочь, не вполне удобный’ (VUB RS F1-D1031, л. 93). Полный переход на немецкий язык.

16 'Паинька мальчик, [я] прочел 48 страниц и почти все понял' (VUB RS F1-D1035, л. 44). Переход включает более двух языков.

17 [в горах] 'главный хребет не был виден' (VUB RS F1-D1030, л. 174), польская лексема была бы grzbiet.

${ }^{18}$ В частности, в дневнике часто не переводятся названия эмоций, что скорее всего связано с различным концептуализированием эмоций в разных языках (Girininkaite, 2017a).

19 'Величайшая ложь'. Польская лексема подается в офранцуженном варианте (VUB RS F1D1051, л. 207v).

20 'Пойми, ведь настроение - это вещь священная. Res sacra' (VUB RS F1-D1035, л. 128).

21 'Я видел сон... я грезил... Sapnavau [аналог по-литовски], все же не так хорошо звучит... Греза Сон’ (VUB RS F1-1050, л. 17v).

22 'И что же они, сукины дети, думают?' (VUB RS F1-1025, л. 74).

23 'Черт побери' (VUB RS F1-1036, л. 71). 


\section{1. Несинхронность переключения кодов}

В тексте ДВЦ неоднократно наблюдалось, что так называемое переключение кодов не является дискретным явлением и на разных уровнях языка происходит не синхронно. К примеру, начав писать фразу по-польски, автор легко мог перейти на русский (или наоборот), но изменение графического начертания букв могло несколько «запаздывать». Например, в польском тексте могло появиться Чорт дери, глупства гада ${ }^{24}$ или такие примеры, как орrисz „шляня'sie“ byłem w Muzeum Czartoryjskich ${ }^{25}$; а въ ocmaтечным razie i jutro ${ }^{26}$. Явление несовпадения языка и его «аутентичной» графики можно пробовать объяснить, выдвинув гипотезу, что для прекрасно владеющего и той и другой графической системой билингва начертание букв не столь важно. Другая догадка, которая могла бы объяснить, как «невнимание» к графике, так и неупорядоченность польской орфографии Цивиньского (несмотря на то, что он постоянно читал по-польски и книги, и периодические издания), касается психофизиологических особенностей его внимания и прежде всего аудиального восприятия мира. Такую догадку, как нам кажется, подтверждает частое и детальное описание в ДВЦ сопутствовавших событиям жизни автора звуков, увлеченность музыкой и его редкая чуткость к особенностям произношения окружающих.

\section{2. Металингвистические наблюдения в Дневнике}

Прилежность учившего иностранные языки Цивиньского сочеталась с его врожденным даром слышать языки и делать металингвистические наблюдения. В тексте ДВЦ довольно часто видны исправления и замечания относительно языковых ошибок, которые молодой человек делал как в своем ранее написанном тексте, так и по ходу его написания. С другой стороны, он болезненно реагировал на неаккуратность, «неправильности» в речи окружающих, в прочитанных им текстах, особенно в переводах. О наблюдательности автора ДВЦ можно судить по тому, что его могло раздражать даже «неправильное» диалектное произношение в речи немца (Nerwóje mnie ten znajomy p[a]na G.[rellet] swoim „isz“, „niszt“, „Laipzig“, ,orbaiten“, „natürlisz“27), или по тому, что он отмечал отличия в произношении у евреев России - и Германии (wchodze

24 'Черт дери, ерунду мелет' (VUB RS F1-D1032, л. 10). л. 116v).

25 'Кроме прогулки [по улицам] я был еще и в музее Чарторыйских' (LMAVB RS F194-10,

26 'А в конце концов и завтра' (VUB RS F1-D1048, л. 10).

27 'Меня раздражает этот знакомый господина Грейе со своими «иш», «ништ», «Лайпциг», «орбайтен», «натюрлиш»' (VUB RS, F1-D1025, л. 50v). 
w „ряды“... dosć czysci žydzi (oni tu mówiq więcej podobnym do niemieckiego narzeczem, niž w Rossyi ${ }^{28}$ ). В ДВЦ довольно много критических замечаний автора об оплошностях в прочитанных им переводах, о стиле написания статей в периодических изданиях.

\section{4. Выводы}

ДВЦ представляет собой любопытный памятник письменности начала XX века и может быть оценен как многообещающий материал для дальнейшего исследования различных аспектов содержания и формы рукописи. Это памятник польского социолекта дворян Литвы, а также хроника изучения автором литовского языка. К тому же это редкий пример столь полной и продолжительной фиксации идиолекта во всем его разнообразии и изменчивости, позволяющей наблюдать взаимодействия различных языков, закономерности их чередования в сознании и речи полилингва. ДВЦ предоставляет также возможность изучать польский язык социальной группы по переписке семьи и знакомых автора дневника. ДВЦ может быть интересен не только лингвистически, но и с точки зрения исторических исследований - исследований истории повседневности, истории фотографии и так далее.

\section{Сокращения}

LMAVB RS - Отдел рукописей и редких изданий Библиотеки Врублевских Литовской академии наук.

SGP - Karłowicz, J. (1900-1911). Słownik gwar polskich. Kraków: Nakładem Akademii Umiejętności.

SJPD - Doroszewski, W. (red.). (1958-1969). Słownik języka polskiego. T. I - XI. Warszawa: Państwowe Wydawnictwo Naukowe.

SWO - M. Arcta słownik wyrazów obcych: 25.000 wyrazów, wyrażeń, zwrotów i przysłów cudzoziemskich, używanych $w$ mowie potocznej i $w$ prasie polskiej (wyd. 7 niezmienione, uwagi wstępne H. Ułaszyna). Warszawa: M. Arct, 1921 + Suplement 2777 wyrazów i wyrażeń, dopetnienie z nowych dziedzin życia i wiedzy, 1927.

USJP - Dubisz, S. (red.).(2003). Uniwersalny słownik języka polskiego. T. 1-4. Warszawa: Państwowe Wydawnictwo Naukowe.

VUB RS - Отдел рукописей библиотеки Вильнюсского университета. ДВЦ - Дневник Витольда Цивиньского.

28 'Вхожу в ряды... довольно опрятные евреи (здесь они говорят на наречии более подобном немецкому, чем в России' (VUB RS, F1-D1030, л. 42). 


\section{Источники}

Geni - электронный ресурс по генеалогии. Retrieved January 30, 2020, from www.geni.com LMAVB RS, F194-1, Civinskis Vytautas. Свидетельство окончания 4 класса Тамбовского реального училища (1902).

LMAVB RS, F194-3, „Przyjaciel dzieci...“ [список книг и статей, прочитанных Витольдом Цивиньским в течение 1894-1907].

LMAVB RS, F194-10, Civinskis Vytautas. Альбом с полученными открытками и письмами [рукопись]. Лотовяны, Лейпциг (1903-1904).

VUB RS, F1-D1024 и до F1-D1052 включительно: Дневник Витольда Цивиньского.

Электронный ресурс по истории края Аникщяй, Retrieved January 30, 2020, from www.anykstenai.lt

\section{Библиография}

Adomavičiūtè-Čekmonienè, I., \& Čekmonas, V. (1999). Polskojęzyczna wysepka pod Oniksztami, której dziś już nie ma (z historii języka polskiego na Litwie rdzennej). In J. Rieger (Ed.), Studia nad polszczyzną kresowa (Vol. 9, pp. 33-76). Wydawnictwo Naukowe Semper.

Arct, M. (1921). Michała Arcta słownik wyrazów obcych: 25.000 wyrazów, wyrażeń, zwrotów i przysłów cudzoziemskich, używanych $w$ mowie potocznej i w prasie polskiej [SWO] (H. Ułaszyn, Intro; 7th ed.). M. Arct.

Arct, M. (1927). Michała Arcta słownik wyrazów obcych: Suplement 2777 wyrazów i wyrażeń, dopetnienie z nowych dziedzin życia $i$ wiedzy [SWO]. M. Arct.

Czeszewski, M. (2001). Słownik slangu młodzieżowego. Wydawnictwo Ekolog.

Doroszewski, W. (Ed.). (1958-1969). Słownik języka polskiego [SJPD] (Vols. 1-11). Państwowe Wydawnictwo Naukowe.

Dubisz, S. (Ed.). (2003). Uniwersalny słownik języka polskiego [USJP] (Vols. 1-4). Państwowe Wydawnictwo Naukowe.

Elspass, S. (2014). The use of private letters and diaries in sociolinguistic investigation. In J. M. Hernández-Campoy \& J. C. Conde-Silvestre (Eds.), The handbook of historical sociolinguistics (pp. 156-169). Wiley Blackwell. https://doi.org/10.1002/9781118257227.ch9

Girininkaite, V. (2017a). Emocijų verbalizavimas keliakalbio diskurse. Atvejo analizė: Vytauto Civinskio Dienoraštis (1904-1910). Taikomoji kalbotyra, 9, 134-148. https://doi.org/ 10.15388/TK.2017.17450

Girininkaite, V. (2017b). Lietuvių kalbos mokymasis XX a. pradžioje. Liudijimai Vytauto Civinskio Dienoraštyje (1904-1910). Žmogus ir žodis, 19(1), 38-49. https://doi.org/10.15823/ zz.2017.3

Girininkaitè, V. (2018). Knygos kultūros apraiškos V. Civinskio Dienoraštyje (1904-1910). Bibliotheka Lituana, 5, 107-134. https://doi.org/10.15388/BiblLita.2018.V.11768 
Girininkaitè, V. (2019). Kalbų ir kultūrų sąveika keliakalbio idiolekte. Atvejo analizè: Vytauto Civinskio Dienoraštis (1904-1910) [Unpublished doctoral dissertation]. Vilniaus universitetas.

Jankauskas, V. (2010). Nenorèjęs (negalëjęs) būti svetimas. Kupiškis, 2010(8), 9-12. http://leidykla.vda.It/Files/file/Kupiškis/Kupiskis_2010.nr8.pdf

Jonikas, P. (1972). Lietuviu bendrinès rašomosios kalbos kūrimasis XIX a. antrojoje pusèje. Pedagoginis lituanistikos institutas.

Karaś, H., Rutkovska, K., Geben, K., \& Ušinskienè, V. (2001). Język polski na Kowieńszczyźnie: Historia, sytuacja socjolingwistyczna, cechy językowe, teksty (H. Karaś, Ed.). Elipsa.

Karłowicz, J. (1900-1911). Słownik gwar polskich [SGP]. Nakładem Akademii Umiejętności.

Koch, P., \& Oesterreicher, W. (1980). Sprache der Nähe - Sprache der Distanz: Mündlichkeit und Schriftlichkeit im Spannungsfeld von Sprachtheorie und Sprachgeschichte. Romanistisches Jahrbuch, 36, 15-43. https://doi.org/10.15496/publikation-20410

Markevičienè, Ž. (2011). Anykštènų patarmès diferenciacija. Lituanistica, 57(3), 305-313. https://doi.org/10.6001/lituanistica.v57i3.2161

Muysken, P. (2000). Bilingual speech: A typology of code-mixing. Cambridge University Press.

Nevalainen, T., \& Raumolin-Brunberg, H. (2014). Historical sociolinguistics: Origins, motivations, and paradigms. In J. M. Hernández-Campoy \& J. C. Conde-Silvestre (Eds.), The handbook of historical sociolinguistics. Wiley Blackwell. https://doi.org/ $10.4324 / 9781315840208$

Palionis, J. (1995). Lietuvių rašomosios kalbos istorija. Mokslo ir enciklopedijų leidykla.

Pasaulio anykštènu bendrija. (n.d.). www.anykstenai.lt

Romaine, S. (2009). Socio-historical linguistics, its status and methodology. Cambridge University Press.

Rutkowska, K. (2012). Lietuvių kalbos skoliniai Lietuvos lenkų tarmèse. Acta Linguistica Lithuanica, 67, 52-77.

Sawaniewska-Mochowa, Z. (2002). Ze studiów nad socjolektem drobnej szlachty kowieńskiej XIX wieku: Na podstawie słowników przekładowych Antoniego Juszkiewicza. Wydawnictwo Akademii Bydgoskiej im. Kazimierza Wielkiego.

Sawaniewska-Mochowa, Z., \& Zielińska, A. (2007). Dziedzictwo kultury szlacheckiej na byłych Kresach pótnocno-wschodnich Rzeczypospolitej: Ginaca część kultury europejskiej. Instytut Slawistyki Polskiej Akademii Nauk (Slawistyczny Ośrodek Wydawniczy).

Smoczyński, W. (2001). O niektórych lituanizmach polszczyzny wileńskiej. In W. Smoczyński, Język litewski w perspektywie porównawczej (pp. 445-460). Wydawnictwo Uniwersytetu Jagiellońskiego.

Trzebińska-Wróblewska, A. (2002). Mój Ojciec: Profesor Józef Trzebiński oczami córki i nie tylko. Wydawnictwo Aula.

Venckienè, J. (2007). The beginning of standard Lithuanian: Ideas and their distribution (18831901) [Unpublished summary of doctoral dissertation]. Vytauto Didžiojo universitetas.

Žilinskaitè, S., Rasimavičius, M., \& Girininkaite, V. (2017). Prof. Juozapas Tšebinskis: Len- 
kijos, Ukrainos ir Lietuvos botanikas, fitopatologas, pedagogas. Universitas Vilnensis, 2017(2(1738)), 14. https://issuu.com/vu_lt/docs/2017-balandis-internetui?gathStatIcon $=$ true

Zinkevičius, Z. (1978). Lietuviu kalbos dialektologija. Mokslas.

Беликов, В. И., \& Крысин, Л. П. (2001). Социолингвистика: Учебник. РГГУ.

Григорьева, Т. М. (2004). Три века русской орфографии (XVIII-XX вв.): Исторический очерк; документы к реформе орфографии до 1917 г.; документы и законодательные акты к реборме 1917 г.; проекты орбографической ребормы после 1917 г.; хронологическая библиография; материаль дискуссии об орбографической реформе 1917 г. Элпис.

\section{Bibliography (Transliteration)}

Adomavičiūtè-Čekmonienè, I., \& Čekmonas, V. (1999). Polskojęzyczna wysepka pod Oniksztami, której dziś już nie ma (z historii języka polskiego na Litwie rdzennej). In J. Rieger (Ed.), Studia nad polszczyzną kresowa (Vol. 9, pp. 33-76). Wydawnictwo Naukowe Semper.

Arct, M. (1921). Michała Arcta słownik wyrazów obcych: 25.000 wyrazów, wyrażeń, zwrotów i przysłów cudzoziemskich, używanych $w$ mowie potocznej i w prasie polskiej [SWO] (H. Ułaszyn, Intro; 7th ed.). M. Arct.

Arct, M. (1927). Michała Arcta słownik wyrazów obcych: Suplement 2777 wyrazów i wyrażeń, dopetnienie z nowych dziedzin życia $i$ wiedzy [SWO]. M. Arct.

Belikov, V. I., \& Krysin, L. P. (2001). Sotsiolingvistika: Uchebnik. RGGU.

Czeszewski, M. (2001). Słownik slangu młodzieżowego. Wydawnictwo Ekolog.

Doroszewski, W. (Ed.). (1958-1969). Słownik języka polskiego [SJPD] (Vols. 1-11). Państwowe Wydawnictwo Naukowe.

Dubisz, S. (Ed.). (2003). Uniwersalny słownik języka polskiego [USJP] (Vols. 1-4). Państwowe Wydawnictwo Naukowe.

Elspass, S. (2014). The use of private letters and diaries in sociolinguistic investigation. In J. M. Hernández-Campoy \& J. C. Conde-Silvestre (Eds.), The handbook of historical sociolinguistics (pp. 156-169). Wiley Blackwell. https://doi.org/10.1002/9781118257227.ch9

Girininkaitè, V. (2017a). Emocijų verbalizavimas keliakalbio diskurse. Atvejo analizè: Vytauto Civinskio Dienoraštis (1904-1910). Taikomoji kalbotyra, 9, 134-148. https://doi.org/ 10.15388/TK.2017.17450

Girininkaitè, V. (2017b). Lietuvių kalbos mokymasis XX a. pradžioje. Liudijimai Vytauto Civinskio Dienoraštyje (1904-1910). Žmogus ir žodis, 19(1), 38-49. https://doi.org/10.15823/ zz.2017.3

Girininkaitè, V. (2018). Knygos kultūros apraiškos V. Civinskio Dienoraštyje (1904-1910). Bibliotheka Lituana, 5, 107-134. https://doi.org/10.15388/BiblLita.2018.V.11768 
Girininkaitè, V. (2019). Kalbų ir kultūrų sąveika keliakalbio idiolekte. Atvejo analizè: Vytauto Civinskio Dienoraštis (1904-1910) [Unpublished doctoral dissertation]. Vilniaus universitetas.

Grigor'eva, T. M. (2004). Tri veka russkoŭ orfografii (XVIII-XX vv.): Istoricheskiŭ ocherk; dokumenty $k$ reforme orfografii do $1917 \mathrm{~g}$.; dokumenty i zakonodatel'nye akty $k$ reforme $1917 \mathrm{~g}$.; proekty orfograficheskoĭ reformy posle 1917 g.; khronologicheskaia bibliografiia; materialy diskussii ob orfograficheskŏ reforme $1917 \mathrm{~g}$. Ėlpis.

Jankauskas, V. (2010). Nenorèjęs (negalèjęs) būti svetimas. Kupiškis, 2010(8), 9-12. http://leidykla.vda.lt/Files/file/Kupiškis/Kupiskis_2010.nr8.pdf

Jonikas, P. (1972). Lietuvių bendrinès rašomosios kalbos kūrimasis XIX a. antrojoje pusejje. Pedagoginis lituanistikos institutas.

Karaś, H., Rutkovska, K., Geben, K., \& Ušinskienė, V. (2001). Język polski na Kowieńszczyźnie: Historia, sytuacja socjolingwistyczna, cechy językowe, teksty (H. Karaś, Ed.). Elipsa.

Karłowicz, J. (1900-1911). Słownik gwar polskich [SGP]. Nakładem Akademii Umiejętności.

Koch, P., \& Oesterreicher, W. (1980). Sprache der Nähe - Sprache der Distanz: Mündlichkeit und Schriftlichkeit im Spannungsfeld von Sprachtheorie und Sprachgeschichte. Romanistisches Jahrbuch, 36, 15-43. https://doi.org/10.15496/publikation-20410

Markevičienè, Ž. (2011). Anykštėnu patarmès diferenciacija. Lituanistica, 57(3), 305-313. https://doi.org/10.6001/lituanistica.v57i3.2161

Muysken, P. (2000). Bilingual speech: A typology of code-mixing. Cambridge University Press.

Nevalainen, T., \& Raumolin-Brunberg, H. (2014). Historical sociolinguistics: Origins, motivations, and paradigms. In J. M. Hernández-Campoy \& J. C. Conde-Silvestre (Eds.), The handbook of historical sociolinguistics. Wiley Blackwell. https://doi.org/ $10.4324 / 9781315840208$

Palionis, J. (1995). Lietuvių rašomosios kalbos istorija. Mokslo ir enciklopedijų leidykla.

Pasaulio anykštènu bendrija. (n.d.). www.anykstenai.lt

Romaine, S. (2009). Socio-historical linguistics, its status and methodology. Cambridge University Press.

Rutkowska, K. (2012). Lietuvių kalbos skoliniai Lietuvos lenkų tarmèse. Acta Linguistica Lithuanica, 67, 52-77.

Sawaniewska-Mochowa, Z. (2002). Ze studiów nad socjolektem drobnej szlachty kowieńskiej XIX wieku: Na podstawie słowników przekładowych Antoniego Juszkiewicza. Wydawnictwo Akademii Bydgoskiej im. Kazimierza Wielkiego.

Sawaniewska-Mochowa, Z., \& Zielińska, A. (2007). Dziedzictwo kultury szlacheckiej na byłych Kresach pótnocno-wschodnich Rzeczypospolitej: Ginąca część kultury europejskiej. Instytut Slawistyki Polskiej Akademii Nauk (Slawistyczny Ośrodek Wydawniczy).

Smoczyński, W. (2001). O niektórych lituanizmach polszczyzny wileńskiej. In W. Smoczyński, Język litewski w perspektywie porównawczej (pp. 445-460). Wydawnictwo Uniwersytetu Jagiellońskiego.

Trzebińska-Wróblewska, A. (2002). Mój Ojciec: Profesor Józef Trzebiński oczami córki i nie tylko. Wydawnictwo Aula. 
Venckiene, J. (2007). The beginning of standard Lithuanian: Ideas and their distribution (18831901) [Unpublished summary of doctoral dissertation]. Vytauto Didžiojo universitetas.

Žilinskaitè, S., Rasimavičius, M., \& Girininkaite, V. (2017). Prof. Juozapas Tšebinskis: Lenkijos, Ukrainos ir Lietuvos botanikas, fitopatologas, pedagogas. Universitas Vilnensis, 2017(2(1738)), 14. https://issuu.com/vu_lt/docs/2017-balandis-internetui?gathStatIcon $=$ true

Zinkevičius, Z. (1978). Lietuvių kalbos dialektologija. Mokslas.

\section{Приложение}

Примерное распределение языков в тетрадях ДВЦ. Единица измерения - исписанная страница (предпоследний столбец); подсчет проводился de visu. При подсчете учитывались лишь страницы, записанные рукой Витольда Цивиньского (не рассматривались полученные им письма и т. д.). В последнем столбце приводится общий объем тетради в листах. Сравнительно малое количество исписанных страниц объясняется тем, что оборотные стороны листов оставлены пустыми, в некоторых местах вклеена либо вложена полученная автором дневника корреспонденция. Подсчет приблизителен, поскольку минимальной его единицей стала половина страницы текста. Хранящаяся в LMAVB RS часть рукописи не учитывалась, т. к. вся она написана по-польски.

\begin{tabular}{|c|c|c|c|c|c|c|c|c|}
\hline 曷 & $\stackrel{50}{0}$ & 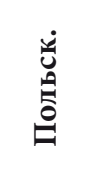 & 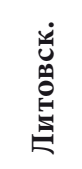 & 岂 & 弟 & 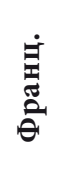 & 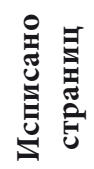 & 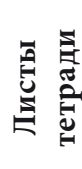 \\
\hline D1024 & 1904 & 161,5 & 5,5 & - & 2,5 & - & 169,5 & 124 \\
\hline D1025 & & 118 & 2 & 2,5 & - & - & 122,5 & 106 \\
\hline D1026 & $1904-5$ & 91 & 0,5 & 1 & - & - & 92,5 & 103 \\
\hline D1028 & & 57,5 & - & 1,5 & 1 & - & 60 & 79 \\
\hline D1029 & & 72,5 & 0,5 & 4,5 & - & - & 77,5 & 85 \\
\hline D1030 & & 103,5 & - & 30 & 7 & - & 140,5 & 210 \\
\hline D1031 & & 77 & 1 & 3 & 135 & - & 94,5 & 103 \\
\hline D1032 & & 77,5 & - & 8 & 56,5 & 2 & 144 & 190 \\
\hline D1033 & $1905-6$ & 48 & 60,5 & 16 & 29 & 0,5 & 154 & 180 \\
\hline D1034 & & 68,5 & 15,5 & 15,5 & 1 & - & 100,5 & 116 \\
\hline D1035 & & 132 & 4 & 17 & 26 & 1,5 & 180,5 & 226 \\
\hline
\end{tabular}




\begin{tabular}{|c|c|c|c|c|c|c|c|c|}
\hline 蓠 & $\stackrel{5}{0}$ & 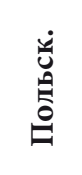 & 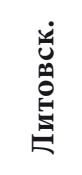 & 岂 & 弟 & 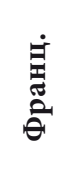 & 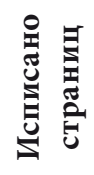 & 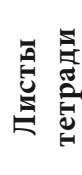 \\
\hline D1036 & $1906-7$ & 47 & 15,5 & 6,5 & 7 & 4 & 80 & 116 \\
\hline D1037 & & 24 & 31 & 11,5 & 8 & 0,5 & 75 & 99 \\
\hline D1038 & & 30,5 & 2 & 0,5 & 1 & - & 34 & 42 \\
\hline D1039 & & 75 & 0,5 & 6,5 & 3 & 0,5 & 85,5 & 99 \\
\hline D1040 & & 72 & - & 1,5 & 2 & - & 75,5 & 92 \\
\hline D1041 & & 49,5 & 46,5 & 10 & - & 0,5 & 106,5 & 144 \\
\hline D1042 & $1907-8$ & 36 & 24,5 & 3 & - & 0,5 & 64 & 99 \\
\hline D1043 & & 8,5 & 56,5 & 6,5 & - & - & 71,5 & 61 \\
\hline D1044 & & 58 & 54 & 6,5 & - & 1,5 & 120 & 152 \\
\hline D1045 & & 64 & 55,5 & 4,5 & - & - & 124 & 154 \\
\hline D1046 & $1908-9$ & 116 & 31,5 & 6 & 0,5 & - & 154 & 143 \\
\hline D1047 & & 111 & 12 & 4,5 & - & 0,5 & 128 & 131 \\
\hline D1048 & & 94 & 46,5 & 4 & - & - & 144,5 & 212 \\
\hline D1049 & & 34 & 139 & 17,5 & - & - & 190,5 & 116 \\
\hline D1050 & & 31,5 & 108 & 4,5 & - & - & 144 & 136 \\
\hline D1051 & 1909-10 & 87,5 & 80,5 & 24,5 & 2 & - & 194,5 & 226 \\
\hline D1052 & & 72,5 & 36 & 2,5 & 0,5 & - & 111,5 & 136 \\
\hline Всего: & & 2018 & 829 & 219,5 & 160,5 & 12 & 3239 & 3759 \\
\hline
\end{tabular}

\section{Языковые особенности Дневника Витольда Цивиньского}

\section{Резюме}

Дневник, написанный студентом Витольдом Цивиньским (1887-1910) (в более поздний период автор пользуется литовским вариантом имени и фамилии Витаутас Цивинскис [Vytautas Civinskis]), представляет собой уникальный многоязычный эгодокумент, который хранится в фондах Вильнюсского университета и Библиотеки имени Врублевских Литовской академии наук. Дневник, составлявшийся в течение шести лет на польском, литовском и русском, также с использованием лексики других языков, дополненный приложенными к нему письмами, другими документами и фотографиями, отражает развитие и изменения лингвистического репертуара автора и черты его языко- 
вой среды. Польский язык Дневника - это язык Кресов, в котором отражается социолект польской шляхты, проживавшей на территории современной Литвы в начале XX в.

В исследуемом источнике можно найти примеры региональной лексики, русизмов и литуанизмов. Кроме того, Дневник дает интересный материал для исследований аукштайтского диалекта литовского языка, которым пользовался Цивиньский, а также хроники освоения автором нового языка. Примеры переключения языковых кодов, которые можно наблюдать в Дневнике, приводят к интересным психолингвистическим выводам касательно двуязычия, а также относительно целесообразности использования нескольких языков для построения поэтической и экспрессивной функции текста. Примеры совмещения автором разных языков в исследуемом источнике предложено называть лингвистическим «монтажом».

Ключевые слова: Витольд Цивиньский; дневник; идиолект; многоязычие; переключение языковых кодов; изучение иностранных языков

\title{
Linguistic Features of the Diary of Witold Cywiński
}

\begin{abstract}
The diary written by student Witold Cywiński (1887-1910) (or Vytautas Civinskis, as he later signed his work with the Lithuanian version of his name) is a unique multilingual egodocument, now held at the Vilnius University Library and the Wróblewski Library of the Lithuanian Academy of Sciences. Written in Polish, Lithuanian and Russian (with additions in other languages) over the period of six years, it shows the evolution of his linguistic repertoire. Along with the attached letters received by the author and drafts of his own letters, it also reflects his sociolinguistic milieu. Borderland Polish used in the diary represents the sociolect of Polish nobility living on the territory of contemporary Lithuania in the early twentieth century, with cases of local lexis and loanwords from Lithuanian and Russian. The passages written in Lithuanian display features of a local variation of the Aukštaitian (High Lithuanian) dialect, and at the same time are a chronicle of the author's self-study of the new language. Examples of code-switching observed in his diary lead to some interesting psycholinguistic conclusions, including the possibility that the author intentionally used a "montage" of different languages in pursuit of the expressive and poetic functions of the text.
\end{abstract}


Keywords: Vytautas Civinskis; diary; idiolect; multilingualism; code-switching; foreign language learning

\title{
Osobliwości językowe Dziennika Witolda Cywińskiego
}

\begin{abstract}
Streszczenie
Pisany przez studenta Witolda Cywińskiego (1887-1910) Dziennik (podpisywany w późniejszym okresie litewską formą imienia i nazwiska diarysty Vytautas Civinskis) jest unikatowym, wielojęzycznym egodokumentem, zachowanym w zbiorach Biblioteki Uniwersytetu Wileńskiego i Biblioteki Wróblewskich Litewskiej Akademii Nauk. Prowadzony przez sześć lat w językach polskim, litewskim i rosyjskim, także z wykorzystaniem leksyki z innych języków, Dziennik razem z dołączonymi do niego listami, innymi drobnymi dokumentami oraz zdjęciami odzwierciedla rozwój i zmiany językowego repertuaru autora oraz cechy jego lingwistycznego otoczenia. Polszczyzna Dziennika to polszczyzna kresowa, reprezentująca socjolekt szlachty litewskiej początku XX stulecia. Badane źródło dostarcza przykładów leksyki regionalnej, rusycyzmów i lituanizmów. Litewski materiał Dziennika może być również interesującym obiektem badań nad auksztajckim dialektem autora, a także kroniką kształcenia się diarysty w nowym dla niego języku. Obserwowane w Dzienniku przełączenia kodów prowadzą do ciekawych wniosków psycholingwistycznych na temat osoby bilingwalnej, jak i ewentualnej celowości używania kilku języków do budowania poetyckiej i ekspresywnej funkcji tekstu. Przykłady łączenia przez autora różnych języków w badanym źródle zaproponowano nazwać „montażem” językowym.
\end{abstract}

Slowa kluczowe: Witold Cywiński; dziennik; idiolekt; wielojęzyczność; przełączanie kodów; uczenie się języków obcych

Dr Veronika Girininkaitė studied Russian linguistics (BA cum laude, 2003) and Slavic philology (MA magna cum laude, 2006) at Vilnius University. Having gained work experience at the Vilnius University Library Manuscript Division, she prepared a PhD thesis in sociolinguistics (2019). While researching the material for her thesis, she published over ten articles on topics related to her studies and to her work on various library manuscripts, participated in international linguistic conferences, and attended the Summer School in Historical Linguistics (Historical Sociolinguistics Network, Leiden 2016). Member of LITAKA (Lithuanian Applied Linguistics 
Association) from 2019. Her scholarly interests focus on multilingualism, historical sociolinguistics and the study of egodocuments.

Bibliography (selected): Emocijų verbalizavimas keliakalbio diskurse. Atvejo analizè: Vytauto Civinskio Dienoraštis (1904-1910) [Verbalising emotions in the discourse of a multilingual: A case study], Taikomoji kalbotyra 9, Vilnius 2017, 134148; Silva rerum termino, žanro bei tipologijos interpretacijos: Vilniaus universiteto bibliotekos rankraščiu atvejis [Understanding the term, genre and typology of Silva rerum: A case study of manuscripts from the Vilnius University Library], Bibliotheca Lituana 4, Vilnius 2017, 41-68; Juozapas Legavičius (1743-1812). Gyvenimas ir raštai [Józef Legowicz (1743-1812): Life and works], Senoji Lietuvos literatūra 43, 2017, 191-213; Knygos kultūros apraiškos V. Civinskio Dienoraštyje (1904-1910) [Manifestations of book culture in the diary of Vytautas Civinskis], Bibliotheca Lituana 5, Vilnius 2018, 107-135.

Correspondence: Veronika Girininkaitè, Vilnius University Academic Library, Vilnius (Lithuania), e-mail: veronika.girininkaite@mb.vu.It

Support of the work: The author received a scholarship from Vilnius University, where she studied while conducting this research.

Competing interests: The author declares that she has no competing interests.

Acknowledgements: As the article is based on part of her doctoral thesis (defended at Vilnius University in 2019), the author would like to thank the academic supervisors of her dissertation: Professor Ala Lihačiova and Professor Krystyna Rutkowska for their guidance and consultations.

Publication History: Received: 2020-01-31; Accepted: 2020-09-19; Published: 2020-12-31. 